\title{
Novel copper complexes as potential proteasome inhibitors for cancer treatment (Review)
}

\author{
ZHEN ZHANG $^{1}$, HUIYUN WANG ${ }^{1}$, MAOCAI YAN $^{1}$, HUANNAN WANG $^{2}$ and CHUNYAN ZHANG ${ }^{1}$ \\ ${ }^{1}$ Institute of Antitumor Drug Research, School of Pharmacy, Jining Medical University, Rizhao, \\ Shandong 276826; ${ }^{2}$ Neurobiology Institute, Jining Medical University, Jining, Shandong 272100, P.R. China
}

Received November 11, 2015; Accepted November 8, 2016

DOI: $10.3892 / \mathrm{mmr} .2016 .6022$

\begin{abstract}
The use of metal complexes in the pharmaceutical industry has recently increased and as a result, novel metal-based complexes have initiated an interest as potential anticancer agents. Copper $(\mathrm{Cu})$, which is an essential trace element in all living organisms, is important in maintaining the function of numerous proteins and enzymes. It has recently been demonstrated that $\mathrm{Cu}$ complexes may be used as tumor-specific proteasome inhibitors and apoptosis inducers, by targeting the ubiquitin-proteasome pathway (UPP). $\mathrm{Cu}$ complexes have demonstrated promising results in preclinical studies. The UPP is important in controlling the expression, activity and location of various proteins. Therefore, selective proteasome inhibition and apoptotic induction in cancer cells have been regarded as potential anticancer strategies. The present short review discusses recent progress in the development of $\mathrm{Cu}$ complexes, including clioquinol, dithiocarbamates and Schiff bases, as proteasome inhibitors for cancer treatment. A discussion of recent research regarding the understanding of metal inhibitors based on $\mathrm{Cu}$ and ligand platforms is presented.
\end{abstract}

\section{Contents}

1. Introduction

2. $\mathrm{Cu}$ and $\mathrm{Cu}$-based complexes

Correspondence to: Dr Zhen Zhang, Institute of Antitumor Drug Research, School of Pharmacy, Jining Medical University, 669 Xueyuan Road, Rizhao, Shandong 276826, P.R. China

E-mail: zhangzhen_1029@126.com

Abbreviations: $\mathrm{Cu}$, copper; DSF, disulfiram; PDTC, pyrrolidine dithiocarbomate; DDTC, diethyldithiocarbomate; CQ, clioquinol; 8-OHQ, 8-hydroxyquinoline; PHEN, 1,10-phenanthroline; PT, pyrithione, UPP, ubiquitin-proteasome pathway; CT, chymotrypsin; $\mathrm{AR}$, androgen receptor; ALDH, aldehyde dehydrogenase

Key words: copper complex, proteasome inhibitor, ubiquitin-proteasome pathway, 8-hydroxyquinoline, clioquinol, dithiocarbamates, Schiff base, 1,10-phenanthroline
3. 8-OHQ and CQ

4. Dithiocarbamates

5. Schiff Base $\mathrm{Cu}$ complexes

6. Further $\mathrm{Cu}$ complexes

7. Conclusions and perspectives

\section{Introduction}

Metal ions are required for the maintenance of numerous critical functions in living organisms and have been used to treat various human diseases (1-4). Platinum-based drugs, including cisplatin and carboplatin (Fig. 1) have been developed as effective anticancer drugs used in chemotherapy of various solid human tumors (5). In addition to platinum-based drugs, complexes of several other metals, including copper $(\mathrm{Cu})$, zinc, gold, palladium and gallium, have demonstrated promising antitumor activities in vitro and in vivo in cancer therapy (6-9). The disulfiram (DSF)- $\mathrm{Cu}$ and clioquinol (CQ)-Cu complexes are being investigated as potential therapeutics for human cancer. Previous results have indicated that these complexes exhibit potent proteasome-inhibitory and apoptosis-inducing activities when the $\mathrm{Cu}$ was transported into cancer cells; however, they are minimally toxic toward normal cells (10-12). The use of metal complexes in the pharmaceutical industry is increasing, thus leading to the development of metal-based complexes as potential anticancer agents.

It has previously been demonstrated that the ubiquitin-proteasome pathway (UPP) is important in controlling the expression, activity and location of various cellular proteins (13). Ciechanover, Hershko and Rose were awarded the Nobel Prize in Chemistry in 2004 for its discovery $(14,15)$. The UPP is responsible for ubiquitination and proteasomal degradation, which regulates cell cycle progression, signal transduction, differentiation, proliferation and apoptosis (16). Tagged proteins are degraded by the $26 \mathrm{~S}$ proteasome, which is localized in the nucleus and cytosol of cells. The $26 \mathrm{~S}$ proteasome is a multicatalytic enzyme complex, which consists of a 20 S catalytic core and two 19S regulatory complexes (17-19). The 20S proteasome consists of four stacked heptameric ring structures, which are composed of two different types of subunits: $\alpha$ and $\beta$ (20). The outer two rings in the stack each consist of seven $\alpha$ subunits, which allow unfolded 
proteins to enter the $20 \mathrm{~S}$ core, whereas $\beta$ subunits in the inner two rings primarily contain three distinct catalytic subunits: $\beta 1, \beta 2$ and $\beta 5$, which are responsible for caspase or peptidyl-glutamyl peptide-hydrolyzing-like, trypsin-like and chymotrypsin (CT)-like activity, respectively (21). Therefore, it has been suggested that proteasomal activity contributes to the pathological development of numerous diseases, including inflammation, neurodegeneration and cancer (22). Notably, it has previously been demonstrated that inhibition of the CT-like activity is associated with induction of tumor cell apoptosis programs $(3,23,24)$.

Selective proteasome inhibition in cancer cells and induction of apoptosis have been regarded as potential anticancer strategies (25). Various proteasome inhibitors have been applied in preclinical experiments and clinical studies as novel anticancer agents (18). Bortezomib (Velcade; Fig. 1) and carfilzomib (Kyprolis; Fig. 1), to the best of our knowledge, are the only proteasome inhibitors that have been granted approval by the US Food and Drug Administration, in 2003 and 2012, respectively $(26,27)$. Bortezomib is a reversible inhibitor of the $26 \mathrm{~S}$ proteasome, which has been used clinically for the treatment of multiple myeloma (MM) and mantle cell lymphoma (28). Carfilzomib is a second-generation proteasome inhibitor, which is primarily used for the treatment of patients with MM following treatment with bortezomib and an immunomodulatory agent $(29,30)$. Proteasome inhibitors have been demonstrated to be highly effective against several cancers in preclinical and clinical trials; however, resistance (2) and toxicity (31-33) have emerged as limiting factors of the continued clinical use of these drugs. A pharmaceutical aim for the future is to continue to develop a novel generation of proteasome inhibitors with far less toxicity and a broader spectrum of activity. Various metal complexes, including gold, $\mathrm{Cu}$ and zinc have been investigated as potential anticancer drugs, due to the success of platinum-based anticancer therapy. Metal-based complexes are currently under investigation due to their ability to exert potent antiproliferative effects by targeting the UPP, resulting in novel opportunities in cancer therapy (23). The present review focuses on recent advances in the development of metal complexes as proteasome inhibitors, with emphasis on $\mathrm{Cu}$ complexes for cancer treatment.

\section{2. $\mathrm{Cu}$ and $\mathrm{Cu}$-based complexes}

$\mathrm{Cu}$ is an essential trace element in all living organisms, which is important in the process of internal oxidation and reduction. All animals, including humans, require a finite amount of $\mathrm{Cu}$ for survival and normal physiological function. $\mathrm{Cu}$ is important in maintaining the correct functionality of proteins and enzymes. Numerous key enzymes require the participation and activation of $\mathrm{Cu}$ to affect metabolic processes in organisms $(34,35)$. Cu levels in serum and tissue have been demonstrated to be significantly greater in various human tumors, including breast (36), prostate (37), colon (37), lung (38) and brain cancers (39). Kuo et al (36) reported that serum and tissue $\mathrm{Cu}$ levels in breast cancer patients were markedly higher than levels in the control group. The serum $\mathrm{Cu}$ concentration was $1,252.20 \mu \mathrm{g} \cdot \mathbf{l}^{-1}$ in the malignant group, followed by the benign group and the control group with the concentrations of $1,038.93$ and $964.95 \mu \mathrm{g}^{\bullet 1} \mathbf{1}^{-1}$, respectively. Furthermore, a
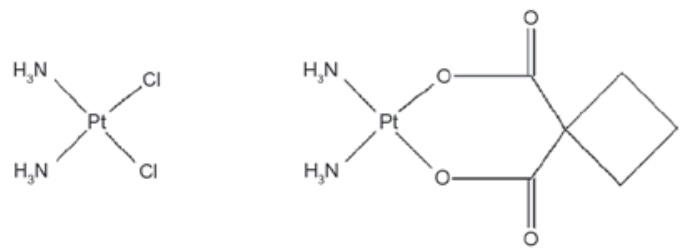

Cisplatin
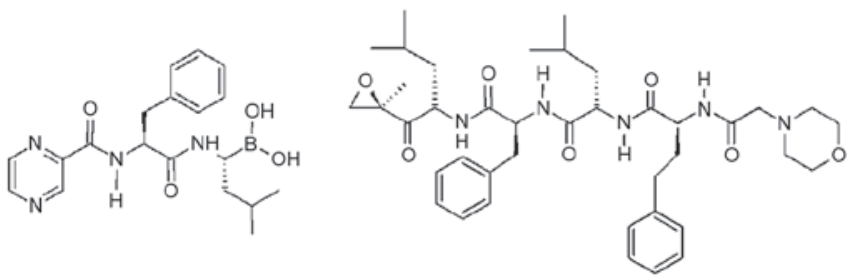

Bortezomib

Carfilzomib

Figure 1. Chemical structures of cisplatin, carboplatin, bortezomib and carfilzomib.

significant difference between normal and malignant tissues in the malignant group was been demonstrated with concentrations 6.13 and $11.3 \mu \mathrm{g}^{\bullet} \mathrm{g}^{-1}$, respectively. A similar result has also been observed in other types of cancer (37-39).

Recent studies have demonstrated that $\mathrm{Cu}$ is associated with angiogenesis (40), which is important in the proliferation, invasion and metastasis of tumor cells $(41,42)$. Therefore, based on the biological function of $\mathrm{Cu}$ in tumor progression, inhibition of angiogenesis by reducing the content of $\mathrm{Cu}$ in vivo may be developed as a novel strategy in cancer therapy $(4,43)$. Daniel et al (44) demonstrated that $\mathrm{Cu}$ complexes inhibited the activity of the $26 \mathrm{~S}$ proteasome in vitro and in vivo. Various chelators, including 8-hydroxyquinoline, (8-OHQ), dithiocarbamate and clioquinol (CQ), may react with $\mathrm{Cu}$ salts and form complexes that act as potent proteasome inhibitors and apoptosis inducers in cultured human cancer cells. Further studies revealed that $\mathrm{Cu}$ complexes demonstrated an inhibitory effect against proteasomes in vitro or in vivo (45-47).

\section{8-OHQ and CQ}

Daniel et al (44) synthesized and tested the anticancer activity of $\mathrm{Cu}$ complexes, including $\left[\mathrm{Cu}(8-\mathrm{OHQ})_{2}\right](8-\mathrm{OHQ}$ is presented in Fig. 2). The $\mathrm{Cu}(8-\mathrm{OHQ}){ }_{2}$ complex was revealed to be potent, transient, proteasome inhibitors capable of inducing apoptosis in human leukemia cells, but not in non-transformed, immortalized human natural cells under the same conditions. Further experimental studies demonstrated that the inhibition of CT-like proteasome activity and apoptotic induction do not result from $\mathrm{Cu}$-mediated oxidative damage to proteins, but from the formation of a proteasome inhibitor inside the tumor cell (43).

CQ (5-chloro-7-iodo-8-hydroxyquinoline; Fig. 2) is an analog of 8-OHQ that has been used to treat Alzheimer's disease in preclinical and clinical trials (48-51). CQ has been demonstrated to bind $\mathrm{Cu}$ and form novel $\mathrm{Cu}$ complexes, which possess proteasome-inhibitory activities and induce apoptosis in cancer cells (44). $\mathrm{Cu}$-chloride $\left(\mathrm{CuCl}_{2}\right)$ has the ability to directly inhibit CT-like activity of purified 20S proteasome, with a half maximal inhibitory concentration value of 
<smiles>Oc1cccc2cccnc12</smiles>

8-OHQ
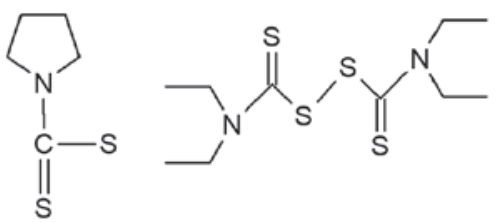

DSF<smiles>Oc1c(I)cc(Cl)c2cccnc12</smiles>

$C Q$

\section{PDTC}

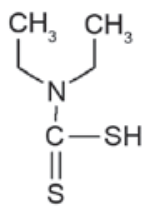

DDTC
Figure 2. Chemical structures of quinoline derivatives and dithiocarbamate derivatives. 8-OHQ, 8-hydroxyquinoline; CQ, clioquinol; PDTC, pyrrolidine dithiocarbamate; DSF, disulfiram; DDTC, diethyldithiocarbamate.

3-5.3 $\mu \mathrm{M}(44,45)$; however, it does not enter cells. CQ alone did not inhibit the CT-like activity of the proteasome; however, the combination of $\mathrm{CQ}$ and $\mathrm{CuCl}_{2}$ resulted in different effects in the same experiment and demonstrated selective inhibitory effects on CT-like activity, but not caspase- or trypsin-like activities $(44,45)$. Subsequently, it was hypothesized that targeting highly elevated $\mathrm{Cu}$ in cancer cells and tissues, in conjunction with treatment with novel compounds including $\mathrm{CQ}$, may result in the formation of tumor-specific proteasome inhibitors that possess potential for cancer therapy.

Chen et al (11) investigated the underlying molecular mechanism of CQ in human prostate cancer cells and xenografts. Inhibition of proteasomal CT-like activity, suppression of androgen receptor (AR) protein expression and induction of cell apoptosis was observed following $\mathrm{CQ}$ binding with $\mathrm{Cu}$. CQ was subsequently administered to mice bearing C4-2B xenografts, and potently inhibited the tumor growth via in vivo proteasome inhibition and apoptotic induction. The study suggested that CQ is capable of targeting the tumor proteasome in vivo depending on the presence of $\mathrm{Cu}$, and subsequently leads to the formation of an AR inhibitor and apoptosis inducer, which is responsible for the observed anti-prostate tumor effect $(11,46)$. In 2009, to further understand the molecular mechanism of CQ and 8-OHQ-mediated antitumor activity, Barrea et al (47) conducted a human prostate tumor xenograft experiment. Elemental mapping and the chemical status of $\mathrm{Cu}$ in tumor and normal tissues collected from the same mice were then measured. The copper in normal tissue and tumor tissue existed predominantly in the form of $\mathrm{Cu}$ (I). Following treatment with CQ, cellular copper could interact with $\mathrm{CQ}$ and convert $\mathrm{Cu}$ (I) to $\mathrm{Cu}$ (II), and thus, $\mathrm{Cu}$ (II) content increased significantly in tumor tissue (47). This conversion of $\mathrm{Cu}$ (I) to $\mathrm{Cu}$ (II) in tumor tissue is associated with CQ-induced proteasome inhibition. Zhai et al (12) revealed that 8-OHQ or $\mathrm{CQ}$, but not their analogs, may bind to $\mathrm{Cu}$ salt and transport the $\mathrm{Cu}$ complex into human breast cancer cells or interact with cellular $\mathrm{Cu}$ to form a complex and consequently result in proteasome inhibition, growth-suppression and apoptotic induction (12). However, further studies are required to verify the use of 8-OHQ or CQ in clinical trials as potential anticancer agents.

\section{Dithiocarbamates}

Dithiocarbamates, which are a class of metal chelating reagents, interact with metal ions and form metal complexes that have been applied as a class of potential agents to target the UPP in cancer treatment. Pyrrolidine dithiocarbamate (PDTC; Fig. 2) is the first member of the dithiocarbamate family, which has been revealed to bind $\mathrm{Cu}$, inhibit the cancer-specific proteasome and induce cellular apoptosis in human breast and prostate cancer. However, PDTC alone failed to exhibit similar results in cultured cells $(45,52)$.

Yu et al (53) and Wang et al (54) synthesized a series of PDTC analogues with substitutions to the pyrrolidine ring, and studied the associations between structure and activity. Following the formation of $\mathrm{Cu}$ complexes, it was observed that the size and polarity of the ring within PDTC affected its activity. When the pyrrolidine ring was substituted with larger and more polar groups in the analogues, the effect on proteasome-inhibitory potencies of the formed $\mathrm{Cu}$ complexes was significantly decreased (53). Furthermore, novel $\mathrm{Cu}$ (II) complexes of PDTC analogues had less aldehyde dehydrogenase (ALDH) inhibition activity and inhibited the CT-like activity of the proteasome in human breast cancer cells (54). Disulfiram (DSF; Fig. 2) was subsequently revealed to have antitumor activities when binding with $\mathrm{Cu}$ and forming a complex. DSF is an irreversible ALDH inhibitor, which has been clinically used for the treatment of alcoholism (55).

Chen et al (10) tested the effects of DSF and a DSF-Cu mixture in cultured breast cancer cells on proteasome inhibition and apoptotic induction. Cell death was observed following treatment with the DSF-Cu complex, however not with DSF alone. Conversely, following an alteration of the $\mathrm{Cu}$ concentration in human breast cancer cells to the $\mathrm{Cu}$ levels present in the patient, DSF alone resulted in a similar biological activity as observed with the DSF-Cu mixture in cultured cancer cells. These results demonstrated that once DSF entered the tumor cells, it was able to react with endogenous $\mathrm{Cu}$, inhibit the proteasome and induce apoptosis in $\mathrm{Cu}$-enriched MDA-MB-231 human breast cancer cells.

This previous finding was further verified following treatment of mice bearing MDA-MB-231 tumor xenografts with DSF. The results indicated that DSF inhibited the tumor growth of mice via proteasome-inhibitory activity (10). Notably, based on these preclinical studies of DSF, the use of DSF in human cancer treatment has been investigated in clinical trials. In addition, diethyldithiocarbamate (DDTC; Fig. 2) is a member of the dithiocarbamate family and a potent chelator of $\mathrm{Cu}$. DDTC is a synthetic immunomodulator that has undergone clinical trials in patients with human immunodeficiency virus-1 infection; DDTC resulted in a significant delay in disease progression to acquired immune deficiency syndrome $(56,57)$. Following binding with $\mathrm{Cu}$, DDTC-Cu (II) (58) and DDTC-Cu (I) (59) complexes significantly inhibited proteasomal CT-like activity and induced apoptosis in breast, prostate and pancreatic cell lines. Furthermore, DDTC-Cu (II) complex inhibited the expression of $\mathrm{AR}$ protein in prostate cancer cells and estrogen receptor proteins in breast cancer cells (58). However, 
<smiles></smiles>

QC-Cu

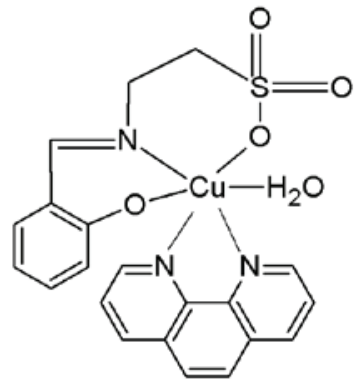

$\mathrm{Cu}(\mathrm{TsS})(\mathrm{PHEN})\left(\mathrm{H}_{2} \mathrm{O}\right)$

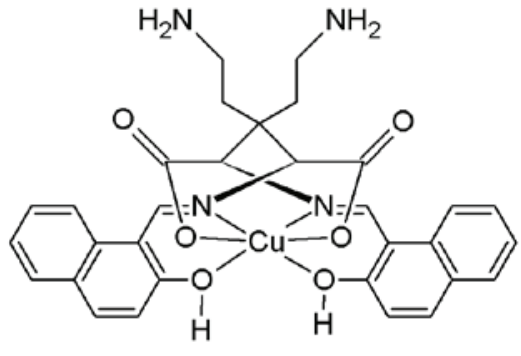

HNO-Cu

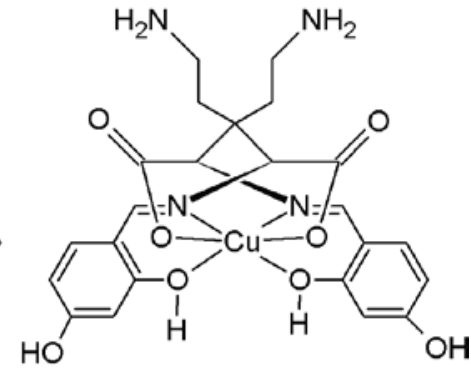

DBO-Cu

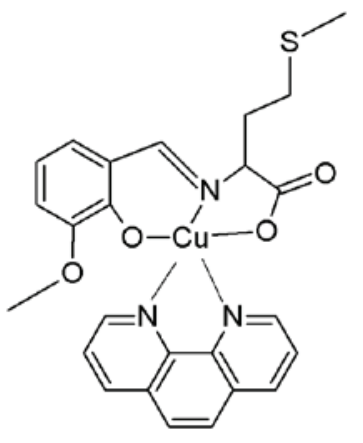

Cu(Mvs)(PHEN)

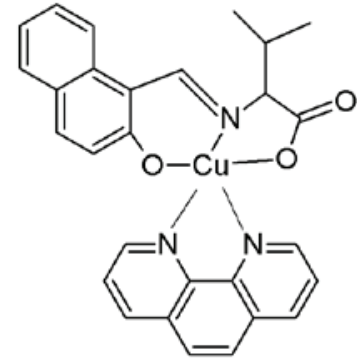

Cu(Vhn)(PHEN)

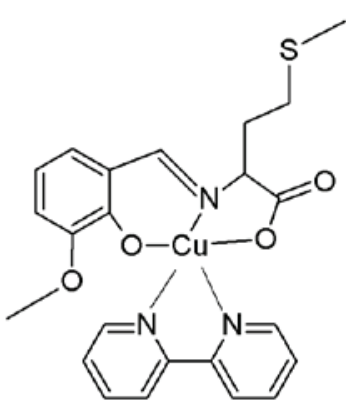

Cu(Mvs)(Bpy)

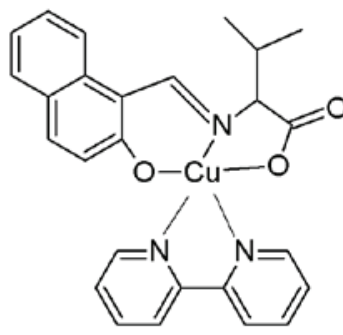

Cu(Vhn)(Bpy)

Figure 3. Chemical structures of Schiff base copper complexes: QC-Cu, Cu(Tss)(PHEN)(H $\left.{ }_{2} \mathrm{O}\right), \mathrm{HNO}-\mathrm{Cu}, \mathrm{DBO}-\mathrm{Cu}, \mathrm{Cu}(\mathrm{Mvs})(\mathrm{PHEN}), \mathrm{Cu}(\mathrm{Vhn})(\mathrm{PHEN})$, $\mathrm{Cu}(\mathrm{Mvs})(\mathrm{Bpy}), \mathrm{Cu}(\mathrm{Vhn})(\mathrm{Bpy})$. QC, quinoline-2-carboxaldehyde; Cu, copper; Tss, taurine salicylic Schiff-base; HNO, 2-hydroxy-1-naphthaldehyde-L-ornithine; DBO, 2,4-dihydroxybenzaldehyde-L-ornithine; PHEN, 1,10-phenanthroline; Bpy, 2,2'-bipyridine; Mvs, L-methionine-o-vanillin Schiff base; Vhn, valine-2-hydroxy-1-naphthaldehyde Schiff base.

increased p27 and decreased nuclear factor- $\kappa \mathrm{B}$ expression was detected with DDTC-Cu (I) treatment in patients with pancreatic cancer (59). The presence of $\mathrm{Cu}$ (I) and $\mathrm{Cu}$ (II) results in the formation of DDTC-Cu (I) and DDTC-Cu (II) in vivo, which may subsequently lead to anticancer activity. These results suggested that increased $\mathrm{Cu}$ in human cancer cells and tissues may be used as a novel targeting method for cancer therapy.

\section{Schiff base Cu complexes}

The Schiff base is a functional group, which includes a double bond between carbon and nitrogen, which may be synthesized by condensation of an aliphatic or aromatic amine and a carbonyl compound. Schiff bases and their metal complexes have been used widely in medicine, catalysis, corrosion protection and analytical chemistry, due to their physiological properties. Schiff bases and their metal complexes have previously been demonstrated to exhibit potent antibacterial and antitumor activity (60-66).

Schiff base $\mathrm{Cu}$ complexes have been investigated as potential anticancer drugs that target the UPP. However, the specific structure of the complex is associated with its anticancer activity. The synthesis of a series of Schiff bases of quinoline-2-carboxaldehyde (QC) and their $\mathrm{Cu}$ complexes (QC-Cu; Fig. 3) was previously reported (61), and these complexes were revealed to exhibit significant antiproliferative activity against PC-3 and LNCaP prostate cancer cell lines.

Notably, the biological activity and function of these complexes is affected by the nature of the side chains at position $\mathrm{C} 2$. An introduction of a thiocarbonyl group at the
$\mathrm{C} 2$ position in the quinoline moiety upon $\mathrm{Cu}$ complexation, demonstrated the greatest cytotoxic activity. Furthermore, Schiff base $\mathrm{Cu}$ complexes are capable of inducing apoptosis via the inhibition of CT-like proteasome activity, however not via oxidative stress in LNCaP prostate cancer cells (61).

1,10-phenanthroline (PHEN) is an important metal chelator with a planar structure. Various metal complexes containing PHEN and Schiff bases possess anticancer activity. These include the taurine Schiff base copper complex [Cu (Tss) (PHEN) $\left(\mathrm{H}_{2} \mathrm{O}\right)$; where Tss is taurine salicylic Schiff-base; Fig. 3], which potently inhibits the activity of the proteasome and induces apoptosis in MDA-MB-231 human breast cancer and Jurkat T leukemia cells (67). This conclusion is consistent with information presented in another report (68). A more recent study has presented the construction of four novel amino acid Schiff base $\mathrm{Cu}$ complexes $[\mathrm{Cu}(\mathrm{Mvs})(\mathrm{PHEN})$, $\mathrm{Cu}(\mathrm{Vhn})(\mathrm{PHEN}), \mathrm{Cu}(\mathrm{Mvs})(\mathrm{Bpy})$ and $\mathrm{Cu}(\mathrm{Vhn})(\mathrm{Bpy})$; where Mvs and Vhn are L-methionine-o-vanillin Schiff base and valine-2-hydroxy-1-naphthaldehyde Schiff base, respectively; Fig. 3], which contain PHEN or 2,2'-bipyridine (Bpy) as the second ligand (68). Cytotoxicity and antiproliferation studies of these $\mathrm{Cu}$ complexes against MDA-MB-231 or MCF-7 human breast cancer cells, and PC-3 prostate cancer cells demonstrated different effects. Notably, $\mathrm{Cu}$ complexes with PHEN as the second ligand were able to inhibit cell growth, proteasome activity and induce cell death; however, the compounds with Bpy as the second ligand did not. The presence of PHEN as part of the complex has therefore been demonstrated to be important in determining cytotoxic activity. The preliminary docking analysis explained why various activities are exhibited between the two substances. The complex $\mathrm{Cu}(\mathrm{Mvs})$ 


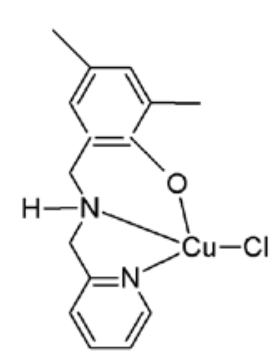

$\mathrm{Cu}(\mathrm{Dpmp}) \mathrm{Cl}$

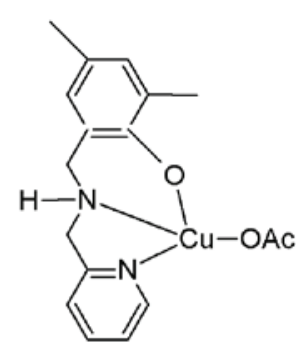

$\mathrm{Cu}(\mathrm{Dpmp}) \mathrm{OAC}$<smiles></smiles>

[Cu(HDpmp)(Dpmp)]OAc

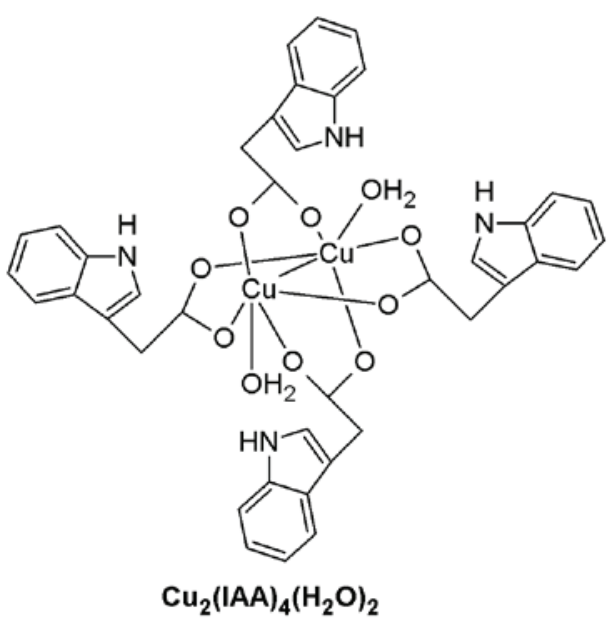

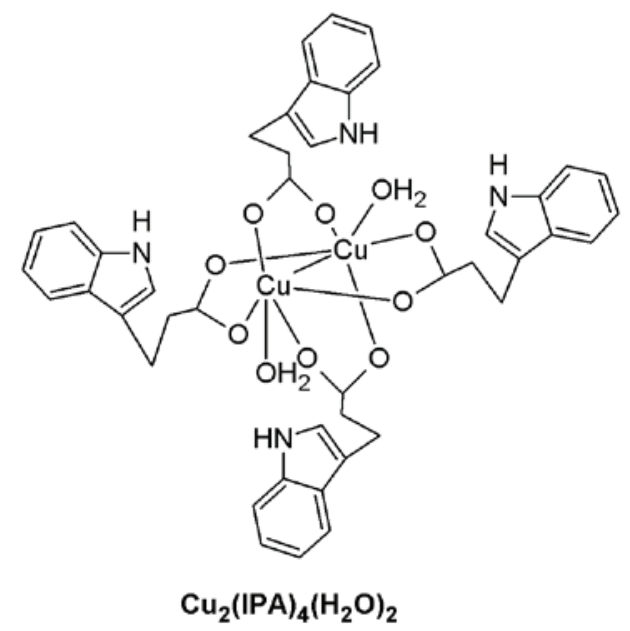

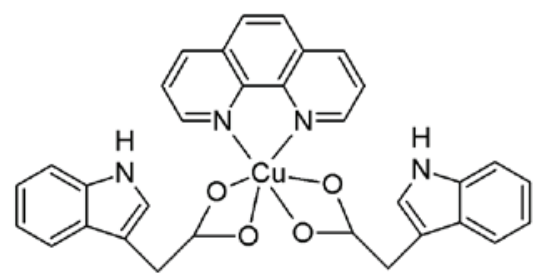

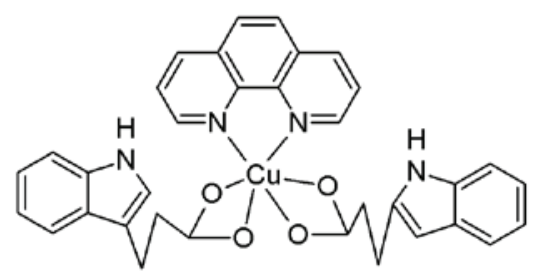

IPA-CU-PHEN

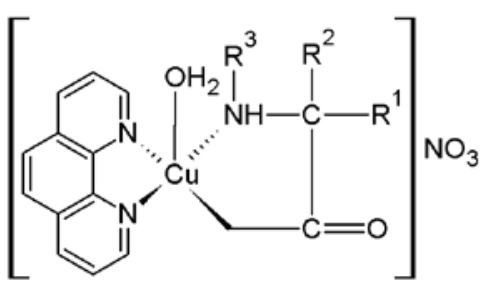

$\left[\mathrm{Cu}(\right.$ phen $\left.)(\mathrm{aa})\left(\mathrm{H}_{2} \mathrm{O}\right)\right] \mathrm{NO}_{3}$<smiles>ClC1Nn2c(nnc2-c2ccccn2)S1</smiles>

cis-[Cu(Adtt) $\left.\mathrm{Cl}_{2}\right] \mathrm{Cl}$

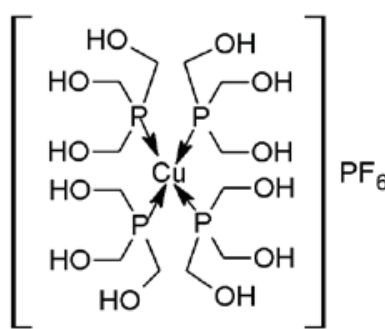

CP

Figure 4. Chemical structures of further copper complexes: $\mathrm{Cu}(\mathrm{Dpmp}) \mathrm{Cl}, \mathrm{Cu}(\mathrm{Dpmp}) \mathrm{OAc},[\mathrm{Cu}(\mathrm{HDpmp})(\mathrm{Dpmp})] \mathrm{OAc}, \mathrm{Cu}(\mathrm{IAA})_{4}\left(\mathrm{H}_{2} \mathrm{O}\right)_{2}, \mathrm{Cu}(\mathrm{IPA})_{4}\left(\mathrm{H}_{2} \mathrm{O}\right)_{2}$, IAA-Cu-PHEN, IPA-Cu-PHEN, [Cu(PHEN)(aa) $\left.\left(\mathrm{H}_{2} \mathrm{O}\right)\right] \mathrm{NO}_{3}$, cis-[Cu(Adtt)Cl$\left.{ }_{2}\right] \mathrm{Cl}$ and $\mathrm{CP}$. Cu, copper; Dpmp, 2,4-diiodo-6-((pyridine-2-ylmethylamino) methyl)phenol; IAA, 3-indole acetic acid; IPA, 3-indole propionic acid; PHEN, 1,10-phenanthroline; $\mathrm{CP}$, [Cu(thp) $\left.{ }_{4}\right]\left[\mathrm{PF}_{6}\right]$; thp, tri(hydroxymethyl)phosphine; aa, methylated glycine, DL-alanine, aarcosine or 2,2-dimethyglycine; Adtt, 4-amino-1,4-dihidro-3-(2-pyridyl)-5-thioxo-1,2,4-triazole.

(PHEN) possesses important intermolecular interactions with the enzymatic pocket and fits exactly to the CT-like binding pocket, thus leading to the reversible inhibition of activity; however, $\mathrm{Cu}(\mathrm{Mvs})$ (Bpy) does not exhibit this property (68).

Schiff base $\mathrm{Cu}$ complexes HNO-Cu (HNO, 2-hydroxy-1-naphthaldehyde-L-ornithine; Fig. 3) and DBO-Cu (DBO, 2,4-dihydroxybenzaldehyde-L-ornithine; Fig. 3) are novel $\mathrm{Cu}$-containing complexes that have been synthesized and compared for their abilities to inhibit the proliferation and induce apoptosis of MDA-MB-231 breast cancer and LNCaP human prostate cancer cells. HNO-Cu suppressed the proliferation in a dose-dependent manner, resulting in $95 \%$ inhibition of cell proliferation at $60 \mu \mathrm{M}$; however, DBO-Cu did not induce significant inhibition of cell proliferation in the cell lines (69). The anticancer activity is therefore dependent on the specific structure of the complex. 


\section{Further $\mathrm{Cu}$ complexes}

A series of $\mathrm{Cu}$ complexes: $[\mathrm{Cu}(\mathrm{Dpmp}) \mathrm{Cl}],[\mathrm{Cu}(\mathrm{Dpmp})$ $\mathrm{OAc}]$, and $[\mathrm{Cu}(\mathrm{HDpmp})(\mathrm{Dpmp})] \mathrm{OAc}$ [where Dpmp is 2,4-diiodo-6-((pyridine-2-ylmethylamino)methyl)phenol; Fig. 4] have recently been reported to demonstrate anticancer activity in vitro against human prostate cancer and leukemia cells (70). Distinctive stoichiometries resulted in three compounds exhibiting different cytotoxicity, and the 1:1 metal-to-ligand complexes were more effective than the 1:2 species. Furthermore, it is necessary for the $\mathrm{Cu}$ (II) ion to interact with the ligand that acts as a carrier to enable crossing of the cell membrane. Once the compound has reached the proteasome of the tumor cell, the metal center of the complex may coordinate to identifiable amino acids, which enable $\mathrm{Cu}-\mathrm{N}, \mathrm{Cu}-\mathrm{S}$ or $\mathrm{Cu}-\mathrm{O}$ bonds to form, thus resulting in proteasome inhibition. Consequently, the active form of the $\mathrm{Cu}$ complex binds to the $\mathrm{N}$-terminal threonine residue of the $\mathrm{CT}$ active center in the $20 \mathrm{~S}$ proteasome (70).

To further investigate the association between biological activity and $\mathrm{Cu}$ complex structure, two types of $\mathrm{Cu}$ complex: Dinuclear $\left(\mathrm{Cu}_{2}(\mathrm{IAA})_{4}\left(\mathrm{H}_{2} \mathrm{O}\right)_{2}\right.$ and $\mathrm{Cu}_{2}(\mathrm{IPA})_{4}\left(\mathrm{H}_{2} \mathrm{O}\right)_{2}$; where IAA and IPA are 3-indole acetic acid and 3-indole propionic acid, respectively; Fig. 4) and ternary (IAA-Cu-PHEN and IPA-Cu-PHEN; Fig. 4) complexes were synthesized, and the effects on cell proliferation and the ability to inhibit the activity of the proteasome were measured (71). It was observed that ternary complexes binding with PHEN as the second ligand were more efficient in carrying $\mathrm{Cu}$ into cancer cells compared with dinuclear complexes, and these complexes consequently resulted in deactivation of the proteasome in PC-3 human prostate cancer cells. In addition, the ternary complexes selectively inhibited the activity of the proteasome and induced apoptosis in tumor cells. The study further supported the hypothesis that carrying $\mathrm{Cu}$ into tumor cells to directly interact with and/or inhibit the proteasome may be applied as a potential anticancer strategy (71).

It has recently been reported that $\left[\mathrm{Cu}(\mathrm{PHEN})(\mathrm{aa})\left(\mathrm{H}_{2} \mathrm{O}\right)\right]$ $\mathrm{NO}_{3}$ (where aa=methylated glycine, DL-alanine, arcosine or 2,2-dimethyglycine; Fig. 4) has been synthesized (72) and demonstrated the ability to induce tumor cell apoptosis via reactive oxygen species generation and proteasome inhibition $(73,74)$. However, these particular complexes did not inhibit CT-like activity of the 20S proteasome in MDA-MB-231 breast tumor cells. However, a higher intensity and greater accumulation of ubiquitinated proteins was observed when cells were treated with the above complexes $(10 \mu \mathrm{M})$. Therefore, proteasome inhibition by these complexes may involve the $19 \mathrm{~S}$ regulatory cap of the $26 \mathrm{~S}$ proteasome or the ubiquitination step (74).

It has previously been demonstrated that a $\mathrm{Cu}(\mathrm{II})$ thioxotriazole complex, cis-[Cu (Adtt) $\left.\mathrm{Cl}_{2}\right] \mathrm{Cl}$ [where Adtt is 4-amino-1,4-dihidro-3-(2-pyridyl)-5-thioxo-1,2, 4-triazole] $(75,76)$ and a phosphine $\mathrm{Cu}(\mathrm{I})$ complex, $\left[\mathrm{Cu}(\mathrm{thp})_{4}\right]$ $\left[\mathrm{PF}_{6}\right](\mathrm{CP}$; where thp is tri (hydroxymethyl)phosphine; Fig. 4), exhibited significantly higher cytotoxic activities compared with cisplatin (77). The cytotoxic effects of $c i s$ - $[\mathrm{Cu}$ (Adtt) $\left.\mathrm{Cl}_{2}\right] \mathrm{Cl}$ and $\mathrm{CP}$ were associated with accumulation of ubiquitinated proteins and inhibition of the UPP in human cancer cells $(76,77)$. The efficacy of $\mathrm{CP}$ was $>40$-fold compared with that of cisplatin in human colon carcinoma cell lines, and therefore demonstrated a notable ability to induce apoptosis. Furthermore, it was able to overcome multi-drug resistance (78). The proteasome-inhibitory activity of the majority of $\mathrm{Cu}$ complexes was primarily studied and optimized in accordance with the capability to specifically block the CT-like active sites. However, CP was able to inhibit all three catalytic sites of the human $26 \mathrm{~S}$ proteasome and therefore induce paraptotic cell death (78) via the activation of endoplasmic reticulum stress signaling, which was consistent with inhibition of the UPP and induction of the unfolded protein response $(76,77)$.

Bortolozzi et al (79) revealed that no mitochondrial involvement was demonstrated in the cell death process when leukemia cell lines were treated with CP. However, the activation of caspase-12, -9, -3 and -7 was observed, indicating that cell death occurred in a caspase-dependent manner. Furthermore, the $20 \mathrm{~S}$ proteasomal chymotrypsin-like activity decreased, ubiquitinated proteins accumulated and endoplasmic reticulum stress increased markedly when CP was present. Notably, CP induced endoplasmic reticulum stress and cell apoptosis in B-acute lymphoblastic leukemia primary cells and synergistically acted with different chemotherapeutic drugs in the treatment of RS4;11 and SEM cell lines.

The combination of pyrithione $(\mathrm{PT})$ and $\mathrm{CuCl}_{2}(\mathrm{CuPT})$ may induce the accumulation of ubiquitinated proteins in cancer cells (80). Furthermore, the mechanism of CuPT may be different compared with that exhibited by the proteasome inhibitor bortezomib. CuPT may also inhibit ubiquitin c-terminal hydrolase L5 and ubiquitin specific peptidase 14 activities, which are associated with the 19S regulatory particles. Therefore, CuPT may inhibit the UPP via targeting proteasome-specific deubiquitinases and 20S proteasome peptidases; an inhibition that may have significant effects in the process of CuPT-mediated cytotoxicity (80).

\section{Conclusions and perspectives}

$\mathrm{Cu}$ is a critical component in cellular metabolism that has been demonstrated to be present at high levels in sera and tissues in various types of human cancer $(36,37)$. It has recently been demonstrated that $\mathrm{Cu}$ and its coordination complexes may exhibit potential as tumor-specific proteasome inhibitors and apoptosis inducers. Two main forms of $\mathrm{Cu}$ chelating compound were investigated for their anticancer properties, and were revealed to exhibit proteasome-inhibitory activities. The prominent classes of metal chelating compounds, dithiocarbamates and 8-OHQs, may result in tumor proteasome inhibition and cell death by targeting elevated levels of tumor-associated $\mathrm{Cu}$. However, the underlying molecular mechanisms of synthesized $\mathrm{Cu}$ complexes may differ depending on the mixture of $\mathrm{Cu}$ and small molecular ligands. The synthetic $\mathrm{Cu}$ complexes inhibit the proteasome by directly interacting with it, thus inhibiting its activity, or by triggering oxidation and deactivation of the cellular proteasome resulting in proteasome inactivation $(41,81)$.

$\mathrm{Cu}$-based compounds have demonstrated positive results in preclinical studies and clinical trials; however, the exact underlying molecular mechanism remains to be elucidated and 
$\mathrm{Cu}$-based compounds are not currently marketed as antitumor agents. $\mathrm{Cu}$ is essential for $\mathrm{Cu}$ complexes to act as proteasome inhibitors and apoptosis inducers; therefore, efforts to develop novel inhibitors based on $\mathrm{Cu}$ and associated ligands are of primary interest. There are at least three important strategies for the selection of ligands of $\mathrm{Cu}$-based compounds during the process of novel metal-based proteasome inhibitor design. Firstly, the selection of various metal chelators, including DSF and $\mathrm{CQ}$, which have been previously approved for the treatment of diseases; secondly, the synthesis of novel $\mathrm{Cu}$ complexes with bioactive natural compounds as ligands, including indole derivatives, pyridine derivatives and Schiff bases; finally, the synthesis of $\mathrm{Cu}$ complexes with compounds that are able to bind effectively to $\mathrm{Cu}$, exhibiting coplanarity/planar structure.

In conclusion, safe and effective metal complexes are required for the development of novel $\mathrm{Cu}$-based inhibitors. In addition, $\mathrm{Cu}$ complexes may be developed into potent proteasome inhibitors that target the UPP and therefore may be used to treat human cancer.

\section{Acknowledgements}

The present study was supported by the Project of Shandong Province Higher Educational Science and Technology Program (grant no. J15LC22 to Z.Z.), the Projects of Medical and Health Technology Development Program in Shandong Province (grant no. 2015WS0413 to Z.Z.) and the Doctoral Foundation of Jining Medical University (grant no. JY14QD06 to Z.Z).

\section{References}

1. Guo Z and Sadler PJ: Metals in medicine. Angew Chem Int Edit 38: 1512-1531, 1999.

2. Schmitt SM, Frezza M and Dou QP: New applications of old metal-binding drugs in the treatment of human cancer. Front Biosci (Schol Ed.) 4: 375-391, 2012.

3. Verani CN: Metal complexes as inhibitors of the $26 \mathrm{~S}$ proteasome in tumor cells. J Inorg Biochem 106: 59-67, 2012.

4. Chen D, Milacic V, Frezza M and Dou QP: Metal Complexes, their cellular targets and potential for cancer therapy. Curr Pharm Des 15: 777-791, 2009.

5. Zhang CX and Lippard SJ: New metal complexes as potential therapeutics. Curr Opin Chem Biol 7: 481-499, 2003.

6. Skrott Z and Cvek B: Diethyldithiocarbamate complex with copper: The mechanism of action in cancer cells. Mini Rev Med Chem 12: 1184-1192, 2012.

7. Berners-Price SJ and Filipovska A: Gold compounds as therapeutic agents for human diseases. Metallomics 3: 863-873, 2011.

8. Fregona D, Giovagnini L, Ronconi L, Marzano C, Trevisan A, Sitran S, Biondi B and Bordin F: Pt(II) and Pd(II) derivatives of ter-butylsarcosinedithiocarbamate. Synthesis, chemical and biological characterization and in vitro nephrotoxicity. J Inorg Biochem 93: 181-189, 2003.

9. Chen D, Frezza M, Shakya R, Cui QC, Milacic V, Verani CN and Dou QP: Inhibition of the proteasome activity by gallium(III) complexes contributes to their anti prostate tumor effects. Cancer Res 67: 9258-9265, 2007.

10. Chen D, Cui QC, Yang H and Dou QP: Disulfiram, a clinically used anti-alcoholism drug and copper-binding agent, induces apoptotic cell death in breast cancer cultures and xenografts via inhibition of the proteasome activity. Cancer Res 66 : 10425-10433, 2006

11. Chen D, Cui QC, Yang H, Barrea RA, Sarkar FH, Sheng S, Yan B, Reddy GP and Dou QP: Clioquinol, a therapeutic agent for Alzheimer's disease, has proteasome-inhibitory, androgen receptor-suppressing, apoptosis-inducing, and antitumor activities in human prostate cancer cells and xenografts. Cancer Res 67: 1636-1644, 2007.
12. Zhai S, Yang L, Cui QC, Sun Y, Dou QP and Yan B: Tumor cellular proteasome inhibition and growth suppression by 8-hydroxyquinoline and clioquinol requires their capabilities to bind copper and transport copper into cells. J Biol Inorg Chem 15: 259-269, 2010.

13. Yang Y, Kitagaki J, Wang H, Hou DX and Perantoni AO: Targeting the ubiquitin-proteasome system for cancer therapy. Cancer Sci 100: 24-28, 2009.

14. Ciehanover A, Hod Y and Hershko A: A heat-stable polypeptide component of an ATP-dependent proteolytic system from reticulocytes. Biochem Biophys Res Commun 81: 1100-1105, 1978.

15. Hershko A, Ciechanover A, Heller H, Haas AL and Rose IA: Proposed role of ATP in protein breakdown: Conjugation of protein with multiple chains of the polypeptide of ATP-dependent proteolysis. Proc Natl Acad Sci USA 77: 1783-1786, 1980.

16. Nalepa G, Rolfe M and Harper JW: Drug discovery in the ubiquitin-proteasome system. Nat. Rev Drug Discov 5: 596-613, 2006.

17. Adams J: The proteasome: A suitable antineoplastic target. Nat Rev Cancer 4: 349-60, 2004.

18. Frezza M, Schmitt S and Dou QP: Targeting the ubiquitin-proteasome pathway: An emerging concept in cancer therapy. Curr Top Med Chem 11: 2888-2905, 2011.

19. Wójcik C and DeMartino GN: Intracellular localization of proteasomes. Int J Biochem Cell Biol 35: 579-2589, 2003.

20. Nandi D, Tahiliani P, Kumar A and Chandu D: The ubiquitin-proteasome system. J Biosci 31: 137-155, 2006.

21. Groll M, Heinemeyer W, Jäger S, Ullrich T, Bochtler M, Wolf DH and Huber R: The catalytic sites of $20 \mathrm{~S}$ proteasomes and their role in subunit maturation: A mutational and crystallographic study. Proc Natl Acad Sci USA 96: 10976-10983, 1999.

22. Dalla Via L, Nardon C and Fregona D: Targeting the ubiquitin-proteasome pathway with inorganic compounds to fight cancer: A challenge for the future. Future Med Chem 4: 525-543, 2012.

23. An B, Goldfarb RH, Siman R and Dou QP: Novel dipeptidyl proteasome inhibitors overcome $\mathrm{Bcl}-2$ protective function and selectively accumulate the cyclin-dependent kinase inhibitor p27 and induce apoptosis in transformed, but not normal, human fibroblasts. Cell Death Differ 5: 1062-1075, 1998.

24. Rajkumar SV, Richardson PG, Hideshima T and Anderson KC: Proteasome inhibition as a novel therapeutic target in human cancer. J Clin Oncol 23: 630-639, 2005.

25. Orlowski RZ and Kuhn DJ: Proteasome inhibitors in cancer therapy: Lessons from the first decade. Clin Cancer Res 14: 1649-1657, 2008.

26. Kane RC, Bross PF, Farrell AT and Pazdur R: Velcade: U.S. FDA approval for the treatment of multiple myeloma progressing on prior therapy. Oncologist 8: 508-513, 2003.

27. Potts BC, Albitar MX, Anderson KC, Baritaki S, Berkers C, Bonavida B, Chandra J, Chauhan D, Cusack JC Jr, Fenical W, et al: Marizomib, a proteasome inhibitor for all seasons: Preclinical profile and a framework for clinical trials. Curr Cancer Drug Tar 11: 254-284, 2011.

28. Kane RC, Dagher R, Farrell A, Ko CW, Sridhara R, Justice R and Pazdur R: Bortezomib for the treatment of mantle cell lymphoma. Clin Cancer Res 13: 5291-5294, 2007.

29. Kuhn DJ, Orlowski RZ and Bjorklund C: Second generation proteasome inhibitors: Carfilzomib and immunoproteasome-specific inhibitors (IPSIs). Curr Cancer Drug Targets 11: 285-295, 2011.

30. Kuhn DJ, Chen Q, Voorhees PM, Strader JS, Shenk KD, Sun CM, Demo SD, Bennett MK, Leeuwen FW, Chanan-Khan AA and Orlowski RZ: Potent activity of carfilzomib, a novel, irreversible inhibitor of the ubiquitin-proteasome pathway, against preclinical models of multiple myeloma. Blood 110: 3281-3290, 2007.

31. Kupperman E, Lee EC, Cao Y, Bannerman B, Fitzgerald M, Berger A, Yu J, Yang Y, Hales P, Bruzzese F, et al: Evaluation of the proteasome inhibitor MLN9708 in preclinical models of human cancer. Cancer Res 70: 1970-1980, 2010.

32. Lee EC, Fitzgerald M, Bannerman B, Donelan J, Bano K, Terkelsen J, Bradley DP, Subakan O, Silva MD, Liu R, et al: Antitumor activity of the investigational proteasome inhibitor MLN9708 in mouse models of B-cell and plasma cell malignancies. Clin Cancer Res 17: 7313-7323, 2011.

33. Sanchez E, Li M, Steinberg JA, Wang C, Shen J, Bonavida B, Li ZW, Chen H and Berenson JR: The proteasome inhibitor CEP-18770 enhances the anti-myeloma activity of bortezomib and melphalan. Br J Haematol 148: 569-581, 2010.

34. Labbe S and Thiele DJ: Pipes and wiring: The regulation of copper uptake and distribution in yeast. Trends Microbiol 7: 500-505, 1999 
35. Tapiero H, Townsend DM and Tew KD: Trace elements in human physiology and pathology. Copper. Biomed Pharmacother 57: 386-398, 2003.

36. Kuo HW, Chen SF, Wu CC, Chen DR and Lee JH: Serum and tissue trace elements in patients with breast cancer in Taiwan. Biol Trace Elem Res 89: 1-11, 2002.

37. Nayak SB, Bhat VR, Upadhyay D and Udupa SL: Copper and ceruloplasmin status in serum of prostate and colon cancer patients. Indian J Physiol Pharmacol 47: 108-110, 2003.

38. Diez M, Arroyo M, Cerdàn FJ, Muñoz M, Martin MA and Balibrea JL: Serum and tissue trace metal levels in lung cancer. Oncology 46: 230-234, 1989.

39. Turecký L, Kalina P, Uhlíková E, Námerová S and Krizko J: Serum ceruloplasmin and copper levels in patients with primary brain tumors. Klin Wochenschr 62: 187-189, 1984.

40. Finney L, Vogt S, Fukai T and Glesne D: Copper and angiogenesis: Unravelling a relationship key to cancer progression. Clin Exp Pharmacol Physiol 36: 88-94, 2009.

41. Fox SB, Gasparini G and Harris AL: Angiogenesis: Pathological, prognostic, and growth-factor pathways and their link to trial design and anticancer drugs. Lancet Oncol 2: 278-289, 2001

42. Rau KM, Huang CC, Chiu TJ, Chen YY, Lu CC, Liu CT, Pei SN and Wei YC: Neovascularization evaluated by CD105 correlates well with prognostic factors in breast cancers. Exp Ther Med 4 231-236, 2012

43. Daniel KG, Harbach RH, Guida WC and Dou QP: Copper storage diseases: Menkes, Wilson's, and cancer. Front Biosci 9 : 2652-2662, 2004.

44. Daniel KG, Gupta P, Harbach RH, Guida WC and Dou QP Organic copper complexes as a new class of proteasome inhibitors and apoptosis inducers in human cancer cells. Biochem Pharmacol 67: 1139-1151, 2004.

45. Daniel KG, Chen D, Orlu S, Cui QC, Miller FR and Dou QP: Clioquinol and pyrrolidine dithiocarbamate complex with copper to form proteasome inhibitors and apoptosis inducers in human breast cancer cells. Breast Cancer Res 7: R897-R908, 2005.

46. Daniel KG, Chen D, Yan B and Dou QP: Copper-binding compounds as proteasome inhibitors and apoptosis inducers in human cancer. Front Biosci 12: 135-144, 2007.

47. Barrea RA, Chen D, Irving TC and Dou QP: Synchrotron X-ray imaging reveals a correlation of tumor copper speciation with clioquinol's anticancer activity. J Cell Biochem 108: 96-105, 2009.

48. Ritchie CW, Bush AI and Masters CL: Metal-protein attenuating compounds and Alzheimer's disease. Expert Opin Investig Drugs 13: 1585-1592, 2004

49. Ritchie CW, Bush AI, Mackinnon A, Macfarlane S, Mastwyk M, MacGregor L, Kiers L, Cherny R, Li QX, Tammer A, et al: Metal-protein attenuation with iodochlorhydroxyquin (clioquinol) targeting Abeta amyloid deposition and toxicity in Alzheimer disease: A pilot phase 2 clinical trial. Arch Neurol 60 1685-1691, 2003

50. Barcia E, Salama A, Fernández-Carballido A and Negro S: Protective effects of clioquinol on human neuronal-like cells: A new formulation of clioquinol-loaded PLGA microspheres for Alzheimer's disease. J Drug Target 19: 637-646, 2011.

51. Mao F, Yan J, Li J, Jia X, Miao H, Sun Y, Huang L and Li X: New multi-target-directed small molecules against Alzheimer's disease: A combination of resveratrol and clioquinol. Org Biomol Chem 12: 5936-5944, 2014

52. Chen D, Peng FY, Cui QC, Daniel KG, Orlu S, Liu JG and Dou QP: Inhibition of prostate cancer cellular proteasome activity by a pyrrolidine dithiocarbamate-copper complex is associated with suppression of proliferation and induction of apoptosis. Front Biosci 10: 2932-2939, 2005

53. Yu Z, Wang F, Milacic V, Li X, Cui QC, Zhang B, Yan B and Dou QP: Evaluation of copper-dependent proteasome-inhibitory and apoptosis-inducing activities of novel pyrrolidine dithiocarbamate analogues. Int J Mol Med 20: 919-925, 2007.

54. Wang F, Zhai S, Liu X, Li L, Wu S, Dou QP and Yan B: A novel dithiocarbamate analogue with potentially decreased ALDH inhibition has copper-dependent proteasome-inhibitory and apoptosis-inducing activity in human breast cancer cells. Cancer Lett 300: 87-95, 2011.

55. Meyer RE: Prospects for a rational pharmacotherapy of alcoholism. J Clin Psychiatry 50: 403-412, 1989.

56. Reisinger EC, Kern P, Ernst M, Bock P, Flad HD and Dietrich M: Inhibition of HIV progression by dithiocarb. German DTC Study Group. Lancet 335: 679-682, 1990.
57. Hersh EM, Brewton G, Abrams D, Bartlett J, Galpin J, Gill P, Gorter R, Gottlieb M, Jonikas JJ and Landesman S: Ditiocarb sodium (diethyldithiocarbamate) therapy in patients with symptomatic HIV infection and AIDS. A randomized, double-blind, placebo-controlled,multicenter study. JAMA 265: 1538-1544, 1991.

58. Pang H, Chen D, Cui QC and Dou QP: Sodium diethyldithiocarbamate, an AIDS progression inhibitor and a copper-binding compound, has proteasome-inhibitory and apoptosis-inducing activities in cancer cells. Int J Mol Med 19: 809-816, 2007.

59. Han J, Li L, Yue X, Chang J, Shi W and Hua Y: A binuclear complex constituted by diethyldithiocarbamate and copper(I) functions as a proteasome activity inhibitor in pancreatic cancer cultures and xenografts. Toxicol Appl Pharmacol 273: 477-483, 2013.

60. Cerchiaro G, Aquilano K, Filomeni G, Rotilio G, Ciriolo MR and Ferreira AM: Isatin-Schiff base copper(II) complexes and their influence on cellular viability. J Inorg Biochem 99: 1433-1440, 2005.

61. Adsule S, Barve V, Chen D, Ahmed F, Dou QP, Padhye S and Sarkar FH: Novel Schiff base copper complexes of quinoline-2 carboxyaldehyde as proteasome inhibitors in human prostate cancer cells. J Med Chem 49: 7242-7246, 2006.

62. Xiao Y, Bi C, Fan Y, Cui C, Zhang X and Dou QP: L-glutamine Schiff base copper complex as a proteasome inhibitor and an apoptosis inducer in human cancer cells. Int J Oncol 33: 1073-1079, 2008

63. Zhong X, Yi J, Sun J, Wei HL, Liu WS and Yu KB: Synthesis and crystal structure of some transition metal complexes with a novel bis-Schiff base ligand and their antitumor activities. Eur J Med Chem 41: 1090-1092, 2006

64. Creaven BS, Devereux M, Karcz D, Kellett A, McCann M, Noble A and Walsh M: Copper(II) complexes of coumarin-derived Schiff bases and their anti-Candida activity. J Inorg Biochem 103: 1196-1203, 2009.

65. Creaven BS, Czeglédi E, Devereux M, Enyedy ÉA, Foltyn-Arfa Kia A, Karcz D, Kellett A, McClean S, Nagy NV, Noble A, et al: Biological activity and coordination modes of copper(II) complexes of Schiff base-derived coumarin ligands. Dalton Trans 39: 10854-10865, 2010

66. Duff B, Thangella VR, Creaven BS, Walsh M and Egan DA: Anti-cancer activity and mutagenic potential of novel copper(II) quinolinone Schiff base complexes in hepatocarcinoma cells. Eur J Pharmacol 689: 45-55, 2012.

67. Zhang X, Bi CF, Fan Y, Cui Q, Chen D, Xiao Y and Dou QP Induction of tumor cell apoptosis by taurine Schiff base copper complex is associated with the inhibition of proteasomal activity. Int J Mol Med 22: 677-682, 2008.

68. Zuo J, Bi C, Fan Y, Buac D, Nardon C, Daniel KG and Dou QP: Cellular and computational studies of proteasome inhibition and apoptosis induction in human cancer cells by amino acid Schiff base-copper complexes. J Inorg Biochem 118: 83-93, 2013.

69. Zhang Z, Bi CF, Fan YH, Zhang N, Deshmukh R, Yan X, Lv X, Zhang P, Zhang X and Dou QP: L-Ornithine Schiff base-copper and -cadmium complexes as new proteasome inhibitors and apoptosis inducers in human cancer cells. J Biol Inorg Chem 20: 109-121, 2015.

70. Hindo SS, Frezza M, Tomco D, Heeg MJ, Hryhorczuk L, McGarvey BR, Dou QP and Verani CN: Metals in anticancer therapy: Copper(II) complexes as inhibitors of the $20 \mathrm{~S}$ proteasome. Eur J Med Chem 44: 4353-4361, 2009.

71. Zhang Z, Bi C, Schmitt SM, Fan Y, Dong L, Zuo J and Dou QP 1,10-Phenanthroline promotes copper complexes into tumor cells and induces apoptosis by inhibiting the proteasome activity. J Biol Inorg Chem 17: 1257-1267, 2012.

72. Zhang S and Zhou J: Ternary copper(II) complex of 1,10-phenanthroline and glycine: Crystal structure and interaction with DNA. J Coord Chem 61: 2488-2498, 2008.

73. Seng HL, Wang WS, Kong SM, Alan Ong HK, Win YF, Raja Abd Rahman RN, Chikira M, Leong WK, Ahmad M, Khoo AS and $\mathrm{Ng} \mathrm{CH}$ : Biological and cytoselective anticancer properties of copper(II)-polypyridyl complexes modulated by auxiliary methylated glycine ligand. Biometals 125: 1061-1681, 2012.

74. Ng CH, Kong SM, Tiong YL, Maah MJ, Sukram N, Ahmade M and Khoo AB: Selective anticancer copper(II)-mixed ligand complexes: Targeting of ROS and proteasomes. Metallomics 6: 892-906, 2014

75. Dallavalle F, Gaccioli F, Franchi-Gazzola R, Lanfranchi M, Marchiò L, Pellinghelli MA and Tegoni M: Synthesis, molecular structure, solution equilibrium, and antiproliferative activity of thioxotriazoline and thioxotriazole complexes of copper II and palladium II. J Inorg Biochem 92: 95-104, 2002. 
76. Tardito S, Isella C, Medico E, Marchiò L, Bevilacqua E, Hatzoglou M, Bussolati O and Franchi-Gazzola R: The thioxotriazole copper(II) complex A0 induces endoplasmic reticulum stress and paraptotic death in human cancer cells. J Biol Chem 284: 24306-24319, 2009.

77. Gandin V, Pellei M, Tisato F, Porchia M, Santini C and Marzano C: A novel copper complex induces paraptosis in colon cancer cells via the activation of ER stress signaling. J Cell Mol Med 16: 142-151, 2012.

78. Marzano C, Gandin V, Pellei M, Colavito D, Papini G,Lobbia GG Del Giudice E, Porchia M, Tisato F and Santini C: In vitro antitumor activity of the water soluble copper(I) complexes bearing the tris(hydroxymethyl)phosphine ligand. J Med Chem 51: 798-808, 2008.
79. Bortolozzi R, Viola G, Porcù E, Consolaro F, Marzano C, Pellei M, Gandin V and Basso G: A novel copper(I) complex induces ER-stress-mediated apoptosis and sensitizes B-acute lymphoblastic leukemia cells to chemotherapeutic agents. Oncotarget 5: 5978-5991, 2014.

80. Liu N, Liu C, Li X, Liao S, Song W, Yang C, Zhao C, Huang H, Guan L, Zhang P, et al: A novel proteasome inhibitor suppresses tumor growth via targeting both $19 \mathrm{~S}$ proteasome deubiquitinases and 20S proteolytic peptidases. Sci Rep 4: 5240, 2014.

81. Gourley M and Williamson JS: Angiogenesis: New targets for the development of anticancer chemotherapies. Curr Pharm Des 6: 417-439, 2000. 